\title{
The specific features of phytoplankton in the reservoirs of Moskva River
}

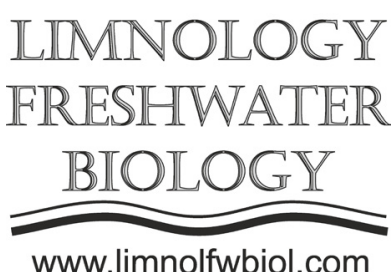

\author{
Goncharov A.V. ${ }^{1 *}$, Puklakov V.V. ${ }^{1}$, Zamana V.G. ${ }^{2}$ \\ ${ }^{1}$ Lomonosov Moscow State University, Faculty of Geography, Leninskie gory, 1, Moscow, 119991 Russia, \\ ${ }^{2}$ JSC Mosvodokanal, Pleteshkovsky pereulok, 2, Moscow, 105005 Russia
}

\begin{abstract}
Analysis is made of perennial changes of phytoplankton in the reservoirs of the Moskva River (Istrinskoye, Mozhaiskoye, Ozerninskoye, and Ruzskoye reservoirs), which serve as sources of water supply for the city of Moscow. It is concluded that phytoplankton is influenced by morphometric parameters of reservoirs, internal phosphorus load, and biotic interactions in the community. The role of the external factor, the river runoff, is great in the upper reaches of the reservoirs, where zones of increased productivity are formed. Climate changes are revealed, leading to transformation of the river runoff and of the internal processes taking place in the reservoir.
\end{abstract}

Keywords: phytoplankton, dimictic reservoirs, the depth of the reservoir, water level, internal phosphorus load

The reservoirs of the Moskva River (Istrinskoye, Mozhaiskoye, Ozerninskoye, and Ruzskoye reservoirs) are a large source of water supply for the city of Moscow. These are valley water reservoirs situated in the upper reaches of the hydrographic network (in the Moskva River and its tributaries Ruza, Ozerna, and Istra rivers). Mozhaiskoye and Ruzskoye reservoirs are morphologically simple, while Ozerninskoye and Istrinskoye reservoirs are complex water bodies, having a large number of bays. All of these are dimictic reservoirs, characterized by stratification of the water body in summer and in winter. These are highly productive reservoirs, in which massive growth of phytoplankton may result in 'blossoming' of water and in other adverse effects.

Our study was based on analysis of the materials of perennial observations conducted by JSC Mosvodokanal over the composition and quality of water in the above reservoirs in 1985-2008; on the results of observations made by the workers of the Krasnovidovo field station of the geography faculty of MSU (1961-2018); the results of publications and of our own observations were also used.

Analysis showed that according to the phytoplankton biomass, the reservoirs may be ranged in the following order: Mozhaiskoye $(3.6 \mathrm{mg} / \mathrm{l})$, Ruzskoye (3.9 mg/1), Ozerninskoye (7.9 mg/l), Istrinskoye (10.8 $\mathrm{mg} / \mathrm{l}$ ) (the mean perennial values of biomass in the vegetation period are indicated). In the same order, the share of blue-green algae increases, and the share of the Diatoms decreases.

The search for the causes of these differences resulted in the fact that the difference in the coefficient of the relative water depth (the ratio between the mean depth and the mean width of a water body, expressed in per mille) (Hutchinson, 1957) is the most probable cause. The coefficient of correlation between this parameter and the above-mentioned biomass values is nearly 1 . The large value of the coefficient of relative water depth indicates sustained thermal stratification of the water mass of a reservoir in the summer period. This means, enrichment of the photic layer with nutrient elements required by algae from the bottom layers becomes difficult. It should be pointed out that in spring, when active convective circulation occurs in water, the differences between the reservoirs become erased.

The seasonal changes of phytoplankton in the reservoirs of the Moskva River are similar to the other reservoirs (lakes) of the temperate zone (Plankton ecology..., 1989). After summer mixing of the water mass carrying biogenic elements to the water surface, fast growth of Diatoms takes place. This is followed by mass reproduction of Daphnia, which feed on algae and lighten the water by filtering it. In June, the phase of 'clear water' begins. After that, the number of Daphnia decreases, as they have destroyed their feeding base. In the middle of the summer, a new rise in the amount of phytoplankton begins: at this time, blue-green algae or dinoflagellates prevail. They are resistant to being eaten by invertebrates, as they are large-sized, or they form massive colonies. In addition, these algae may move vertically and choose the most favorable conditions in terms of illumination and the concentration of nutrient

*Corresponding author.

E-mail address: mama15333@mail.ru (A.V. Goncharov)

(C) Author(s) 2020. This work is distributed under the Creative Commons Attribution 4.0 License. 
elements. Under conditions of scarcity of nitrates and ammonium, the blue-green algae may use atmospheric nitrogen, exercising nitrogen fixation.

It is noteworthy that in the most productive Istrinskoye reservoir, the maximum phytoplankton biomass is observed in summer, while in the less productive Ruzskoye reservoir it is observed in spring, after convective mixing of the water mass. In summer, there is much less phytoplankton here: it seems that the scarcity of nutrient elements plays its role, as their inflow from the bottom layers to the water surface is more difficult due to the greater depth of the said reservoir.

In the said reservoirs, lengthwise inhomogeneity of phytoplankton distribution is very important. For example, in Ruzskoye reservoir, phytoplankton biomass consistently decreases from the upper areas to the dam, being $5.2 \mathrm{mg} / 1$ in Ostashevo, $4.6 \mathrm{mg} / 1$ in Shcherbinki and $2.6 \mathrm{mg} / \mathrm{l}$ in the near-dam area (the mean perennial values of biomass in the vegetation period are indicated). Such a character of algae distribution may be explained by the fact that the Ruza River permanently carries nutrient elements coming there from the watershed. In addition, in shallow areas, the waters of the upper reaches get warm and mixed easier than in the deep near-dam area.

In the reservoirs of the Moskva River, interannual changes in the amount of the phytoplankton biomass are rather important. To clarify the causes of this phenomenon, correlation coefficients were calculated between the amount of the phytoplankton biomass and certain hydrological and hydrochemical parameters. As a result, a reverse relation was revealed between the phytoplankton biomass and the level and volume of water in the reservoirs; this is especially characteristic for the near-dam areas of Ozerninskoye $(r=-0.78)$,
Ruzskoye ( $r=-0.73)$, and Mozhaiskoye ( $r=-0.54)$ reservoirs. Such a relation may be explained by the fact that at the low level of water in a reservoir, the probability of mixing of the water mass and of the outflow of nutrient elements from the bottom layers to the surface is higher. The water level in the reservoirs depends not only on the dryness of the year but also on the specifics of hydrotechnical management of the reservoir.

Thus, in the reservoirs considered, the role of the internal factors of phytoplankton growth is great, including the morphometric parameters of the reservoirs, biotic interactions and the internal phosphorus load. The role of the external factor, the river runoff, is large in the upper reaches of the reservoirs. Hydrometeorological events, including climate changes, leading to transformation of the river runoff and of the internal processes in the reservoir and influencing the phytoplankton growth, make a large impact, too.

\section{Acknowledgements}

This study has been conducted with the support of the Russian Foundation for Basic Research (project № 18-05-01066) and State Assignment AAAA-A16116032810054-3.

\section{References}

Hutchinson G.E. 1957. A treatise on limnology. V. 1. Geography, physics, and chemistry. New-York: John Wiley \& Sons Inc.

Plankton ecology: succession in plankton communities. 1989. In: Sommer U. (Ed.). Berlin, Heidelberg, New York: Springer-Verlag. 